\title{
GNB2 wt Allele
}

National Cancer Institute

\section{Source}

National Cancer Institute. GNB2 wt Allele. NCI Thesaurus. Code C52672.

Human GNB2 wild-type allele is located within 7q21.3-q22.1 and is approximately $5 \mathrm{~kb}$ in length. This allele, which encodes guanine nucleotide-binding protein $G(I) / G(S) / G(T)$ subunit beta 2 protein, is involved in the regulation of seven-transmembrane domain receptor-mediated signal transduction. 